\title{
Weber per Meter
}

National Cancer Institute

\section{Source}

National Cancer Institute. Weber per Meter. NCI Thesaurus. Code C68916.

A SI unit of magnetic vector potential. 